\title{
THE DEVELOPMENT OF RESEARCH-BASED LEARNING MODEL AND JOURNAL AS FOR GRADUATE STUDENTS' SCIENTIFIC PUBLICATIONS OF M.Pd.E ON ECONOMIC
}

\author{
Yulhendri $^{*}$, Efrizal Syofyan ${ }^{* *}$, Silsiya Afridona* \\ ${ }^{*}$ Postgraduate, Master of Economic Education \\ ** Faculty of Economic, Universitas Negeri Padang \\ DOI: 10.29322/IJSRP.8.5.2018.p7764 \\ http://dx.doi.org/10.29322/IJSRP.8.5.2018.p7764
}

\begin{abstract}
The ability of Students in the Master Economic Education - FE UNP in writing the qualified articles are still low. The thesis proposed still only based on previous research, not based on the data and relevant article. The research development aims to develop teaching materials and research-based learning model in the lecture of Economics and Macroeconomics Learning Strategy and as a comparison class were learning accounting. The aims of this research is improving students' ability in conducting a research and writing scientific journals and. The method used was a research design, which consists of three stages, i.e. preliminary design, teaching experiment, and retrospective analysis to improve the students' analytical capabilities. Research output is publications of national and international scientific journals.
\end{abstract}

Index Terms- Research-Based Learning, Intellectual Skills, scientific article, Problem based learning, Inquiry

\section{INTRODUCTION}

$\mathrm{T}$ he educational strategy is an important indicator that is capable of changing the human thoughts from less understand to be more comprehend the matter occured as a whole. The improvement of comprehension capacity were in cognitive, affective, and psychomotor domain. Students is intellectuals positioned as $5 \%$ of nation's population in Indonesia which obliged to improve self quality particularly in order to improve the quality of nation in general with the knowledge learned during the education on campus in accordance with certain scientific fields.

The science obtained through the educational process at college should be implemented in students' life, one of those ways such as conducting scientific research. The research conducted by students can develop themselves, moreover it contributes many benefits for the progress of civilization and the interests of the nation in an effort to improve welfare. In addition to scientific and academic selfdevelopment, the student must constantly develop his or her own skills in softskill and self-maturity in solving all problems. Students must develop a critical mindset against all existing phenomena and study them scientifically.

The methods and development of science is a systematics and objective plan with the following stages : 1) observe and define problems and goals; 2) formulate hypotheses; 3) develop a research plan; 4) carry out the experiments based planned method; 5) conduct the observation and data collection; 6) analyze and interpret data; and 7) formulate conclusions or theories (Dalman, 2013: 9).

In an effort to improve academic skills, it is required a learning strategy which are able to explore the level of students' rationality, that is research-based learning model. Students are supposed to have the capability to think rationally about an economic, social, and politics issues in their daily life, then the capability to analyze those matters happened and think about and alternative solutions to these problems. It is assumed to be capable of raising the level of intellectual skills of students.

Research-based learning is a multifaceted concept that describes the new face of a learning strategy that links between research and teaching. Practicing a good research-based learning should involve four aspects include: 1) The results of the study should have an impact on the curriculum, 2) methods of teaching and learning must be based on research, 3) learning should use research elements, 4) RBL should be able to develop a context of inclusive research (Blackmore \& Fraser, 2007). 
Lockwood (2001: 1) explains that the research-based learning is a learning system that uses authentic learning, problem-solving, direct inquiry and discovery approach, referring to the constructivist philosophy. The benefits of this model have been widely recognized for several decades, but research in the classroom has not been done by many experts as a learning method. Thus, RBL is a learning model that uses authentic learning, problem-solving, cooperative learning, contextual (hands-on and minds-on) and the inquiry discovery approach.

Basically, research-based learning aims to create a learning process that leads to activity analysis, synthesis, and evaluation, and improve the ability of students and professors in terms of assimilation and application of knowledge. The destination can be described as follows: 1) Increase the meaningfulness of the course to make it more contextual with describing the research results. 2) Strengthening the thinking ability of students as researchers. 3) Complete learning through the internalization of research, practice, and research ethics by involving research. 4) Improve the quality of research at the university and involve students in research activities. 5) Enhance student understanding of science through the development of an ongoing investigation. 6) Increase understanding of the role of research in innovation so as to encourage students to think creatively in the future. 7) Improve the quality of education in general (Widyawati, Diah Tri et al., 2010).

One of most important indicator should be concerned in the research-based learning is the involvement of research elements in the learning process. This is because research-based learning (RBL) is authentic with the perspective of the problem formulation, alternative solutions, and how the implementations of the research results can provide benefits in the form of ways and levels of student thinking.

Research-based learning can improve academic achievement, increase the target level of education up to the level of how to learn and build new knowledge that is beneficial to themselves and the environment (Blackmore \& Fraser, 2007). These competencies are very important for education in the 21st century (Brew, 2010).

The phases of research based learning model by Arifin (2010) consisted of three steps. Firstly, Exposure Stage is carried out to determine the ability of early students. Secondly, Experience Stage is the step of administering to conduct research experience. Thirdly, Capstone Stage is the final stage of research by presenting research results orally and in writing.

The excellence of RBL Model expressed by Toisuta (2012) that is a research-based learning model that featured not only develop the ability to discover and communicate knowledge but is also able to integrate ethical and moral decisions both individually and collectively useful for private and public. Research-based learning has a component of "social learning" to develop self-confidence and social solidarity in order to function effectively in a society that is constantly changing.

The RBL concept is a new learning method that enriches students with a variety of research experience. RBL is not only expected to improve students' academic ability, but also improve motivation, active learning, and development of capabilities, such as critical analysis, teamwork, time management and resources.

Benefits of RBL are concerned that RBL may develop inquiry critical attitude, a lot of ideas, and creative solutions. Other benefits revealed by Dafik (2015) as follows: (1) Encourage faculty to conduct research and always updating their knowledge; (2) To encourage the role of students in the learning process, and be research partners; (3) Students are accustomed to thinking process with a scientific approach; (4) Students have the independence, logical, critical, and creative; (5) Students are trained ethics, ethics, in particular, abstain from plagiarism behavior.

The development of science and technology grow rapidly in various part of the world, therefore the research based learning is an appropriate model used in the learning on higher education. As we know that RBL (Research Based Learning) have not only capability to improve the students knowledge, but also increase cognitive skills, thinking skills, and creative in thinking and learning. Students are guided to the active learning, and continuously searching for the latest research results, do analyzing then synthesizing and its implementation to discover the new science. Previous studies have proved that research-based learning is more effective than conventional learning methods (Johnston et al., 2009; Luanganggoon; Choeisuwan 2015). However, the impact of socio-cultural factors on RBL is poorly comprehended in Asia (Johnston et al., 2009).

In line with that, based on the experience of researchers that many higher education institutions have implemented a variety of learning methods, but little is oriented on developing the ability to write a scientific paper on the student. In essence, a scientific paper presents the idea of a systematic problem solving is presented objectively and honestly use language that is supported by the facts, theory and empirical evidence.

Various new findings in science can be traced through papers. Scientific papers resulting from solving a problem-based inquiry, observation, a collection of data obtained from a research, both field studies, laboratory tests, or a literature review based on the ideas (methods) are logical and empirical science. 
Those perception above strengthen this research, by conducting each structured steps in research based learning model, including 1) describes in detail the concept of the lectures so that students understand the main purpose of the content subjects are studied, 2) outlines the topics of lectures, in brief, provides guidance on finding journals that are relevant to the topic, 3) ask the students do a review of several international journals relevant obtained a student, then narrated the results of the analysis in the scientific literature brief, incorporating gap theory found in the journal, 4) lecturer assesses students' writing, 5) to follow up on the results of student writing assessment, by giving new assignment, ask students seeking more international journals relevant to the topic and narrated in a more scientific papers. The next steps 6) to evaluate the performance of the students, 7) spread out a questionnaire about students' perceptions of research-based learning, supplemented with quantitative analysis of the perceptions of students, 8) targets the end of step this research is a scientific journal of the ideas of the students that will be published in journals nationally indexed.

Benefits of RBL are concerned that RBL may develop inquiry critical attitude, a lot of ideas, and creative solutions. Other benefits revealed by Dafik (2015) as follows: (1) Encourage faculty to conduct research and is always updating their knowledge; (2) To encourage the role of students in the learning process, and be research partners; (3) Students are accustomed to thinking process with a scientific approach; (4) Students have the independence, logical, critical, and creative; (5) Students are trained ethics, in particular, abstain from plagiarism behavior.

But in fact, it is difficult to motivate students to write a scientific paper, for instance in a journal. Many student do not understand how to write a good journal, and do not have enough knowledge to write journal especially international journals. Other factors are the student's knowledge of the theories used in research is very limited, still based on the old theory, and context used is still based on common sense. That requires a strong effort to shape the mindset of students that writing a scientific paper is one form of improved quality of a university graduates. Basically, the RBL concept is a new learning method that enriches students with a variety of research experience. RBL is not only expected to improve students' academic ability, but also improve motivation, active learning, and development of capabilities, such as critical analysis, teamwork, time management and resources. Based on this, the goal of this research is :

1. Improve the motivation to write scientific journal of students.

2. Change the research scheme from the research which based on old theories to the research based on new theories and research results.

3. Change the students' mindset in writing scientific journal which still based on common sense into a writing based on current relevant research.

4. Improve the students knowledge about the international journal.

5. Improve the students ability in writing scientific journal.

\section{IDENTIFY, RESEARCH AND COLLECT IDEA}

In the first year of this research, it used research and development design (R and $\mathrm{D})$. The development research consist of several activities, those are collecting, processing, analyzing, and presenting data which were carried out systematically and objectively followed by activities to develop a product to solve the problem occurred. The development research is the research methods used to produce a specific product and test the effectiveness of the product (Sugiyono, 2012: 407).

The research was conducted on Economic Education Master Program Universitas Negeri Padang with samples are students of level X and XI academic year on three subjects, they are Macroeconomic Advanced Theory, The Advanced of Economic Studies Strategy, and International Accounting. This research was conducted with some procedures. These procedures included the planning, exploration, initial product development, validation and final revision. The first stage was the planning which consisted of the formulation and preparation the research steps of research based learning instructional tools development for the subjects of The Advanced of Economic Studies Strategy and Macroeconomic Advanced Theory and International Accounting. The second stage was exploration. Exploration phase included the process of documenting the results of research in areas of topics study based on the syllabus.

The third stage was the initials development of products, such as the revision of the syllabus (if necessary), the construction of lecture unit (SAP), instructional video materials, assignments design, cases, exercises and problems to be discussed in the following classes where learning model applied. The preparations of these learning tools were done with the involvement of a team of lecturers on Economic learning strategies and optimize available e-learning that has been available in e_learning.unp.ac.id.

The first validation steps is validation of theoretical which pursued through expert examination or panelists who assessed the research results selected on the articles downloaded from the source of international journals that were reputable in the last 10 years, and also the instructional tools prepared. This step was conducted through a Focus Group Discussion (FGD) with the lecturer and IT expert 
team as described previously. In addition it will also be involved some students to see the initial responses of students to articles from journals that have been downloaded.

Furthermore, for the second year of this research will develop into a design. research Design research is considered a research paradigm that aims to develop a sequence of activities and comprehend an empirical understanding of how a learning works (Cobb et al., 2003; Edelson, 2002; Gravemeijer, 2004; Research Advisory Committee, 1996; Widjaja, 2008). Wang \& Hannafin (in Wijaya 2008) also defines design research as a systematic but flexible method, aimed at improving teaching practice through repetitive analysis, repetitive design, and implementation, refers to collaborations between researchers and practitioners with daily life situations, and leads to the principles and theories of contextual sensitive design.

\section{RESULTS AND DISCUSSION}

\section{A. The description of the initial Skill}

The initial skill of students was measured with several steps, those are $: 1$ ) give the students a topic in the learning process, 2) students were asked to discover the issues related to the topics given through previous relevant research as the reference, 3 ) and they were asked to make a short contexture article, which consist of problem description, explains the gap theory contained in the referenced journal, and compare with the problems that students encountered. From the results of initial skills test obtained the achievement that students do not have yet the better knowledge and ability to do problem analysis according to the topic given. It attests a necessary to implement the research-based learning model that stimulates students' rational abilities.

\begin{tabular}{|c|c|c|c|c|c|}
\hline \multirow{2}{*}{ No. } & \multicolumn{3}{|c|}{ Interval } & \multicolumn{2}{|c|}{ Pre-Test } \\
\hline & & & & $\mathrm{Fi}$ & $\mathrm{Fi} \%$ \\
\hline 1 & 33.33 & - & 42.31 & 1 & $4.8 \%$ \\
\hline 2 & 42.33 & - & 51.32 & 0 & 0 \\
\hline 3 & 51.33 & - & 60.32 & 0 & 0 \\
\hline 4 & 60.33 & - & 69.32 & 6 & $28.6 \%$ \\
\hline 5 & 69.33 & - & 78.32 & 6 & $28.6 \%$ \\
\hline 6 & 78.33 & - & 87.32 & 8 & $38 \%$ \\
\hline \multicolumn{4}{|c|}{ Total } & 21 & $100 \%$ \\
\hline \multicolumn{4}{|c|}{ Mean } & \multicolumn{2}{|c|}{72.67} \\
\hline \multicolumn{4}{|c|}{ mode } & \multicolumn{2}{|c|}{65} \\
\hline \multicolumn{4}{|c|}{ Median } & \multicolumn{2}{|c|}{85} \\
\hline \multicolumn{4}{|c|}{ Standard Deviation } & \multicolumn{2}{|c|}{13.06} \\
\hline
\end{tabular}

Source: Processed Primer Data 2017

The table above describes the student's initial ability before being treated experimentally. In the experimental class the number of students who have low ability 1 person and student who has high ability as much as 20 people. Then in the control class there are no students who have low initial ability and students who have high initial ability as many as 11 people.

For the average class, the experimental class is 72.67 , while for the control class is 85 . The overall experiment class value is lower than the control class. The low average score of the students in the experimental class because the students have not yet understood the concept of the learning given.

\section{B. The Improvement of Students Ability after Treated Experimentally}

In the pretest, students were only asked to narrate 1 journal and in the posttest after being treated, the students were asked to make a review of 5 books and 10 journals which internationally accredited. This step was conducted to reveal the improvement of students' rational skill and the ability to write scientific journal, and also to do the test to the implementation of research-based learning development model. Posttest is used to see students' ability in both sample classes after being treated by different learning process.

The assessment method of students skill from the posttest refers to the hierarchy of Bloom's Taxonomy (2002) with 6 indicator students' ability assessment those are : 1) remember (C1), 2) understand (C2), 3) apply (C3), 4) analyze (C4 ), 5) evaluate (C5), and 6) create (C6). 
From the posttest results on research based learning model in experiment class obtained the results decrease on students ability. This caused by the low learning motivation of students start from reading, identifying, rewriting, and evaluating a journal. From those 6 indicator only few students that reached anlysis level.

\begin{tabular}{clc}
\hline No. & \multicolumn{1}{c}{ Indicators } & Number of Students \\
\hline 1. & Knowing (C1) & 18 \\
2. & Understanding (C2) & 18 \\
3. & Apply (C3) & 18 \\
4. & Analyze (C4) & 11 \\
5. & Evaluate (C5) & 8 \\
6. & Creating (C6) & 2 \\
\hline
\end{tabular}

The table above describes from 18 students who are treated with research-based learning model, all students have reached the ability of C1, C2, C3 level. However, for C4, C5, C6 levels, the results are varied. For the analysis (C4) of 18 samples there were only 11 students, the ability to evaluate (C5) only 8 students, and the ability to create (C6) there are only 2 students. This data indicates the level of students ability in writing a scientific journal is still low. The ability to write a scientific journal is an ability categorized at the level of creation (C6) because the development of research-based learning model is product-oriented that include writing scientific journal and qualified research proposals, and also learning modules.

While the students' writing intensity is assessed by several criteria including: 1) quality and quantity of reference used, 2) reference recency, 3) national and international accredited journal reference sources, 4) application used in citation, 5) depth of discussion. Among those five assessment criteria, the researcher concludes that there are 3 competencies that can be used as reference indicators of assessment, including: 1) writing ability, 2) combining relevant research into paragraphs, 3) Critical thinking and writing skills.

Basically the orientation of a learning is a process, not a result. The level of remember, understand, apply includedin low ability category of thinking, students will be able to create when they have the ability to analyze and evaluate as a form of critical thinking skills. As expected with the application of research-based learning this will occur a shift in the level of students' thinking ability, from low-level thinking processes to higher-order thinking processes (Krathwol, 2002). In addition, the education level of of this research sample is the Master of Economics Program students with postgraduate level, which at this level students should have a higher order thinking skill level.

Based on the results of the research, there are improvements in the 3 aspects of students' ability related to experiments conducted by implementing research-based learning. The first aspect is students ability to write, the results show that there is an increase in the students ability in writing. The average writing ability of students increased by $30.3 \%$, so the students ability in writing is $68.6 \%$ in the category of quite good. This result can be seen from the task of scientific work done by the students. The second aspect of combining relevant research into a series of paragraphs. In this aspect there was an increase in the students' ability up to $46.5 \%$. It can be concluded that the ability improvement amount $22.5 \%$ is characterized by the ability in constructing the words in theoritical review on students' scientific writings are categorized well. The third aspect is the ability to think and write critically, research results show there is an increase in the students ability to think and write critically. The final result of students' critical thinking and writing skills is $67,6 \%$.

Based on the experiment implemented, it can be concluded that the research based learning model have improved the students' scientific thinking ability, but it has not achieved a significant improvement. This is proven by the test results obtained in classes of The Advanced of Economic Studies Strategy, Macroeconomic Advanced Theory, and International Accounting. Most of the students have only reached C3 level, that is apply level.

\section{CONCLUSION}

Based on the results of the discussion in this research can be drawn some conclusions are as follows:

1. Research-based learning is a form of learning model which is in the process of its implementation using scientific journals, research results and relevant research related to lecturing materials.

2. In general, the steps in research-based learning consist of the preparation stage, the methodology application stage and the research and publication stage.

3. The main problems faced by students in finding scientific journals are lack of ability to find journals that are relevant to the desired topic, and lack of knowledge related to indexed journal sources.

4. The main problems faced by students in making scientific writing such as lack of motivation and experience for scientific writing, lack of understanding of students about the rules of scientific writing well and correctly, difficulty in avoiding plagiarism and lack 
of ability in using supporting applications in writing such mendeley.

5. The ability to write scientific students of the Master Program of Economic Education FE UNP especially on The Advanced of Economic Studies Strategy, Macroeconomic Advanced Theory, and International Accounting is still relatively low. This is reflected in the scientific writings of students who have not been in accordance with applicable standards of scientific writing rules.

\section{SUGGESTION}

Based on the results and discussion of research described previously, there are several things that can be recommended, there are:

1. There should be a follow-up to improve the writing skills of students scientific Master Program of Economic Education FE UNP.

2. Lecturer of the courses should provide further insight on how to cite a scientific journal to improve students' ability in writing a scientific article.

3. It is suggested to give the training for students in using the supporting software in scientific writing as Mendeley etc.

4. Students are required to write a scientific journal continously to improve the experience of scientific writing.

5. The college should provide a medium for students to acquire journals and scientific articles that were indexed and reliable.

\section{REFERENCES}

[1] Arifin, Zainal. 2010. Penelitian Pendidikan Metode dan Paradigma Baru. Bandung: Remaja Rosdakarya.

[2] Blackmore\&Fraser. 2007. Research-Based Learning Strategies for successfully linking teaching and research [online] Available from : https://www.griffith.edu.au/learning-futures/pdf/gihe_tipsheet_web_rbl.pdf

[3] Brew, A., \& Brew, A. 2010. Higher Education Research \& Development Imperatives and challenges in integrating teaching and research Imperatives and challenges in integrating teaching and research, (June 2013), 37-41. https://doi.org/10.1080/07294360903552451.

[4] Cobb, Paul, Confrey, Jere, diSessa, Andrea, Lehrer, Richard and Schauble, Leona. 2003. Design Experiments in Educational Research. DOI: 10.3102/0013189X032001009 Educational Researcher 2003 32: 9. Published on American Educational Research Association and Sage. Cobb et al., 2001; Edelson, 2002; Gravemeijer, 2004; Research Advisory Committee, 1996; Widjaja, 2008

[5] Dafik. 2016. Pengembangan PBR (Pembelajaran Berbasis Riset). Hand Out PBR UNEJ. Universitas Negeri Jember, 1-16.

[6] Dalman. 2013. Keterampilan Menulis. Jakarta: Rajawali Pers. Johnston JM. 2009. A randomised controlled trial of two education modes for undergraduate evidence based medicine learning. Asia BMC Med Educ. (2009) Sep 29;9:63. doi: 10.1186/1472-6920-9-63.

[7] Lockwood, Fred. 2001. Innovation in Open and Distance Learning: Successful Development of Online and Web Based Learning. Routledge, Taylor and Francis Group, London and New York

[8] Nuchwana, L. 2012. International Conference on Education and Educational Psychology (ICEEPSY 2012) How to Link Teaching and Research to Enhance Students' Learning Outcomes: Thai University Experience. Procedia - Social and Behavioral Sciences, 69(Iceepsy), $213-219$. https://doi.org/10.1016/j.sbspro.2012.11.401.

[9] J. Wang, "Fundamentals of erbium-doped fiber amplifiers arrays (Periodical style—Submitted for publication)," IEEE J. Quantum Electron., submitted for publication.

[10] Sugiyono. 2012. Metode Penelitian Pendidikan: Pendekatan Kuantitatif, Kualitatif dan R\&D. Bandung : Alfabeta

[11] Toisuta, W. 2013. Pelatihan Bagi Perancangan Pelatihan. Jakarta: The institute Good governance and ragional development (IGGRD).

[12] Widyawati, Tri Diah, U. G. M. 2010. Pedoman Umum Pembelajaran Berbasis Riset (PUPBR). Universitas Gajah Mada, 15.

\section{Authors}

First Author - Yulhendri, Lecturer, Faculty of Economic, Universitas Negeri Padang

Email : yulhendriunp@gmail.com

Second Author - Efrizal Syofyan, Lecturer, Faculty of Economic, Universitas Negeri Padang

Email :

Third Author - Silsiya Afridona, Post Graduate Student, Faculty of Economic Universitas Negeri Padang

Email : silsiyaafridona@gmail.com

Correspondence Author - Yulhendri, yulhendriunp@gmail.com, +62811664965 